
醸割合との関係を調べてみた。比較的相関の大きかったのは glutamic acid/phenyl alanine 比, 乳酸・コハク酸/グライコール酸比, Xanthoprotein 反応值, Buffer action 值, $\alpha-$ アララーゼ力 価, 全硬度, 無機塩等であった。特飞 Glutamic acid/phenyl alanine 比は有効な手段であると思 われた。これらの方法を用いて市販みりてを分析し增䤑割合を推定したところ調味液量 $l$ : 白米 $\mathrm{kg}$ 比で $0.4 \sim 1.2$ に入るものが多く增醽が比較的広く行なわれていることが推定された。

\section{緒}

\section{言}

最近，新みり几，塩みりん，発醅調味料等が本みりん の競合商品として市場に多くでまわるよらになってき た。これらのものは酒税法の対衆外のものが多く, 原料 面，製造面での特別の制限がないものが多い。したがっ てコストも比較的安く，かつそれぞれ品質上の特徴をも っているものが多い。価格が安い等の理由のためにみり ん市場でのこれら商品の進出は著しいものがあり，これ らの商品に対抗するために本みりんもコストダウンとか 品質上の特徴が要求されるようになってきた。このよう な理由で本みりんの品質も種々変化に富んだものになり つつあり，最近特に増醸歩合が増大しつつあるように思 われる。そこで堌醉みりんの判別法についての試験を行 ないある程度の判別が可能と思われる結果が得られたの で報告する。

\section{実 験 方 法}

\section{1. 一般分析}

総酸度, アミノ酸度, 色度, ボーメ度, 直糖, 全糖, $\mathrm{pH}, \alpha-$ アミラーゼ力価浪ついては国税庁所定分析法 ${ }^{11}$ に したがい行なった。

\section{2. 粘 度}

オストワルド粘度計を用いて $20^{\circ} \mathrm{C}$ で測定し Centi poise (C.P.) で示した。

\section{Xantoprotein 反応值}

主として佐藤の方法8) にしたがって行なったが，その ままでは濃すぎるので試料 $2 \mathrm{~m} l$, 蒸留水 $3 \mathrm{~m} l$, 濃硝酸

* 甘強酒造株式会社
$2 \mathrm{~m} l$ を添加, $30^{\circ} \mathrm{C}, 30$ 分加温後濃アンモニア $2 \mathrm{~m} l$ を 添加し, $430 \mathrm{~m} \mu$ で比色し, セル液厚 $10 \mathrm{~mm}$ を用い OD で表わした。

\section{Millon 反応值}

佐藤らの方法9になない行なった。

\section{Buffer action 值}

サンプル $20 \mathrm{~m} l$ を取り $1 / 10 \mathrm{~N} \cdot \mathrm{NaOH}$ 液にて滴定し， $\mathrm{pH} 9$ になるまでに要する滴定数值で表わした。

\section{6. 全硬度}

国税庁所定分析法1)の水の方法をとのまま利用した。

\section{Glutamic acid/phenylalanine 比の定量}

実験化学講座の方法2) にならいLeuconostoc mesentereuides (Glutamic acid $の$ 定量), Laci. arabinosus (phenylalanine の定量) を使用する Bioassay 法によ り両アミノ酸を定量し，その量比で表わした。

\section{8. 吸光度の測定}

EPR-2 型日立自記分光光度計を用い $400 \sim 800 \mathrm{~m} \mu$ の 間の吸光度を測定した。

\section{9. 乳酸 : コハク酸/グライコール酸比の定量}

中村らの方法3) にならいシリカゲルカラムクロマトグ ラフィーにより各酸量を分別定量し，その量比を計算に より出した。

\section{0. 無機塩の定量}

みりんサンプルを灰化し, 希塩酸に溶解後原子吸光法 により定量した。

\section{1. リン}

国税庁所定分析法1)により定量した。ただし，みりん そのままでは濃すぎるので適当に希釈後定量した。

\section{2. みりん製造}


もち米の精白は $85 \%$ ， 万るち米の精白は $80 \%$ ，焼酎 （アルコール濃度 $40 \%$ ）歩合 $65 \%$, 総米 $500 \mathrm{~g}$ の小仕 込試験を行なった。麳歩合は $10,14,17 \%$ の 3 段階に 分けて試験し, 增醸試験は白米重量（g）飞対する調味 液 $(\mathrm{m} l)$ 比で $0.5,1.0,1.5,2.0$ 倍になるようと調味 液を加年製造した。るろみ日数は 60 日，もろみ温度は 最初の 7 日間を $25^{\circ} \mathrm{C}$ 位, 以後徐々に下げて $18 \sim 15^{\circ} \mathrm{C}$ 前後にたもった。製造したものの分析は上槽後 1 ケ月目 に拉り引き後上澄部分について行なった。

\section{実 験 結 果 \\ 1. 成分分析結果と增䤑との関係 \\ 1）総酸度，アミノ酸度}

第 1 表にあるように両者之増醸との間に特別な関係は みられないが，これは增醸みりんをつくる場合に普通行 なわれているよらに酸度, アミノ酸度が通常のみりんと 同じ位になるよらに製造したのであるから両者に差のみ られないのが当然である。

2) $\mathrm{pH}$

表にあるように堌醸することによって $\mathrm{pH}$ が低くなっ ている。これは原料の液状糖の $\mathrm{pH}$ が低いこと (4.4) と 調味液の Buffer action が小さいためみりんと同じ酸度 にすると $\mathrm{pH}$ が低くなるといらこと等のためと思われ る。この例の場合は $\mathrm{pH}$ と増醸との相関は大きいが第 5 表にもあるように増醉しなくても $\mathrm{pH}$ の低いものもあり 増醸でも比較的高い場合もある。製造用水，原材料等製 造条件によって相当変動が考兄られるので，これによっ て堌醉割合を推定することは問題が多い上うに思われ る。

\section{3）色 度}

增醇によって色度が相当小さくなっている。アミノ酸 度が同じ上らになるようにしても增醇みりんの方が色が 薄くなっている。調味液の色が薄いために增醸及りんも 色が薄くなるのである。増醸によりどんな色が減少して いるかを知るために自記分光光度計で可視部の吸収を調 べたのが第 1 図である。No.1，No. 2 が 2 倍増醇みりん で，No.3，No. 4 が増醸しないるりんである。600〜400

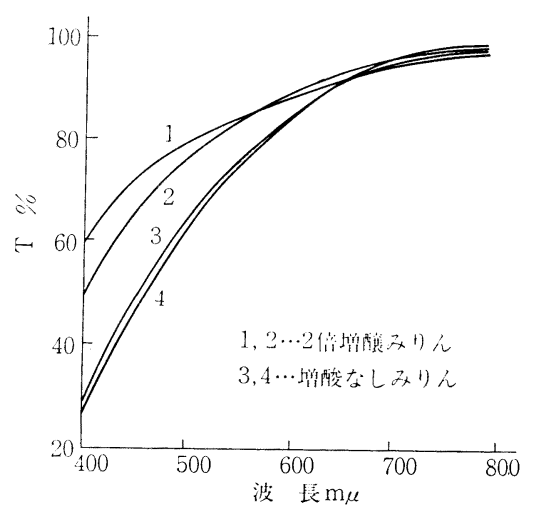

第 1 図本味淋, 増醸味淋の可視部吸光度

$1,2 \cdots \cdots 2$ 倍增醉みりん

$3,4 \cdots \cdots$ 增酸なしみりん

$\mathrm{m} \mu$ あたりの可視部の短い波長の部分に顕著な差がみら れる。しかし色度は貯蔵中に増大する（第 5 表）ので色 度のみで増醸を推定するのは問題があるが，しかし増醸 みりんの色度は長期間貯藏後も增醸しないるりんにくら べやや小さいので推定の一成分として利用できることも たしかである。

4） $\alpha$-アミラーゼ力価

表にあるよらに增醇することにより められるので当然力洒の減少がみられる。注涪堌醇に比 例して減少している。しかし, もろみの棅歩合, 使用麳 の酵素力価, 酵素剂の使用, 貯蔵日数等の増醅以外の条 件により或程度 $\alpha$ アミラーゼ力価の变動が予想されるの で增醸推定の場合には注意が必要と思われる。

\section{5) 粘 度}

増醇することによって粘度が増大している。これは増 醸に使用した液状糖の粘度が高く (37.1 C. P.), 調味液 を製造した場合も粘度が高くなった（12.6 C. P., 12.9 C.P.) ためである。ただし調味液の粘度が高いのはその 中に含まれているデキストリンが多いのが大きな原因で あるので，製造直後は粘度が大であっても，これを貯蔵 しておくとみりん中のアミラーゼによってデキストリン が分解されるので粘度は徐々にさがり差がなくなってく る(第 6 表)。したがって粘度が高い場合には增醸を考

第1表本味淋执よび増醇味淋分析結果

\begin{tabular}{|c|c|c|c|c|c|c|c|c|c|c|c|c|c|c|}
\hline & 総酸度 & $\begin{array}{l}\text { アミ゙ } \\
\text { 酸度 }\end{array}$ & 色度 & ボーメ & 粘度 & 直糖 & 全糖 & $\begin{array}{l}\text { Xantho } \\
\text { protein } \\
\text { 反忘值 }\end{array}$ & $\begin{array}{l}\text { Millon } \\
\text { 反応值 }\end{array}$ & $\begin{array}{c}\text { Buffer } \\
\text { action } \\
\text { 値 }\end{array}$ & $\begin{array}{l}\alpha ア ミ \\
\text { ラーゼ } \\
\text { 力価 }\end{array}$ & $\mathrm{pH}$ & 全硬度 & リン \\
\hline 本 味 & 0.6 & 1.1 & 0.15 & 20.6 & 11.3 & 41.8 & 45.2 & 0.45 & 0.28 & 11.4 & 58.2 & 5.3 & 46.2 & 72 \\
\hline 同增醸 $(1: 1)$ & 0.6 & 1.2 & 0.08 & 20.4 & 12.1 & 40.1 & 44.7 & 0.20 & 0.14 & 7.0 & 24.0 & 5.0 & 34.0 & 44 \\
\hline 同增醉 $(1: 2)$ & 0.6 & 1.2 & 0.05 & 20.3 & 12.2 & 38.3 & 44.5 & 0.11 & 0.09 & 6.3 & 12.6 & 4.8 & 25.2 & 32 \\
\hline 本 味 淋 II & 0.7 & 1.2 & 0.14 & 20.3 & 11.7 & 40.2 & 44.5 & 0.44 & 0.29 & 10.5 & 46.2 & 5.5 & 44.4 & 65 \\
\hline 同增醉 $(1: 1)$ & 0.7 & 1.2 & 0.095 & 19.9 & 12.4 & 39.6 & 44.8 & 0.18 & 0.13 & 7.1 & 18.0 & 4.9 & 35.1 & 41 \\
\hline 同增醇 $(1: 2)$ & 0.7 & 1.2 & 0.065 & 19.8 & 12.5 & 37.9 & 45.2 & 0.07 & 0.08 & 6.4 & 8.4 & 4.7 & 28.6 & 32 \\
\hline 本味淋盀 （古） & 0.6 & 1.2 & 0.16 & 19.9 & 11.4 & 41.9 & 44.6 & 0.51 & 0.29 & 11.2 & 40.2 & 5.6 & 54.0 & 85 \\
\hline 同増醸 $(1: 2)$ & 0.5 & 1.1 & 0.12 & 20.2 & 11.5 & 41.7 & 45.1 & 0.12 & 0.11 & 6.0 & 9.6 & 5.2 & 30.4 & 38 \\
\hline
\end{tabular}


えてよいが，增醉でも低い場合もありうる。又粘度に影 響するものとしてアルコール度数, ボーメ度等もあり, 粘度のみから増醇を推定するのは問題が多いように思わ れる。

6) ボーメ度

増醸に使用する調味液のボーメを何度にするかはその 時の製造計画によって自由に変えるものであるので, 通 常は表にあるとおり増醇とボーメ度との間の相関は考え られない。

7) 直糖, 全糖

通常調味液製造に使用する液状糖は $\mathrm{DE}^{*} 70 \sim 80$ のも のが多いので増醉することによって值糖の方に変化を生 ずる可能性がある。全糖の方はボーメを葟汸一定にする 関係で表にあるように堌醸と特別な関係はみられない。 増醇歩合が大さくなると直糖\%が減少しているが全糖 はあまり差がない。ただし長期間貯蔵するとみりん中の アミラーゼによってデキストリンが分解されてくるので 徐々に直糖\%が増大して遂には増醇しないものとの間 に差がなくなってしまう（第 6 表）。したがって直糖の 少ないものは増醇か上槽直後のものと推定してよいが, 直糖が多いから増醸していないとはいえない。な特調味 液製造に液状糖を使用せず結晶ブドウ糖とか DE 90 以 上の液状糖を使用した場合には最初から通常の本みりん との差はあまりないはずである。

8） Xanthoprotein 值, Millon 反応値, Buffer action 值

いずれも増醉みりんの方が低い值になっている。醇造 みりん中ではペプタイドが薄められて少ないためと思わ れる。Buffer action 值にはアミノ酸も関与すると思わ れる。同表にあるようにアミノ酸量はほぼ等しくしてあ るのでこの場合の差にはアミノ酸はあまり関係ないもの と考えられる。ベプタイド量は製造方法（蒸米の加圧, 無圧, 引ろ又温度, 䊝歩合等) によって相当大きな差が あること年10,11)がわかっているので，この方法だけで増 醇割合を推定する場合にはやや問題があるように思われ る。

9）全硬度，無機塩

第 1 表にあるよらに全硬度, リンともに堌醸すること によって減少している。調味液中にはこれら成分が少な いためと考えられる。さらに無機成分のうち何の差異が 大きいかを調べたところ第 2 表のように增醹により $\mathrm{Na}$ が増大し，Kが減少していることがわかった。 Na が増 大するのは $\mathrm{Na}$ が液状糖に多量にふくまれているためで あると考劣られる。

\footnotetext{
* dextrose equivalent の略, 環元糖（グルコースと して)の固形分に対する百分率
}

第 2 表 增䤈と無機塩との関係

\begin{tabular}{|c|c|c|c|c|c|}
\hline & & $\mathrm{Na}$ & $\mathrm{K}$ & $\mathrm{Mg}$ & $\mathrm{Ca}$ \\
\hline & I & 516 & 220 & 44 & 4 \\
\hline 味 & II & 400 & 205 & 54 & 5 \\
\hline 淋 & III & 433 & 174 & 31 & 3 \\
\hline 增 & $\begin{array}{c}\text { IV } \\
(1: 0.5)\end{array}$ & 1023 & 170 & 29 & 4 \\
\hline 醕 & $(1: 1)$ & 1291 & 116 & 28 & 3 \\
\hline 淋 & $(1: 2)$ & 1533 & 91 & 30 & 3 \\
\hline
\end{tabular}

第 3 表 味淋中の glutamic acid, phenylalanine 含量 $\mathrm{r} / \mathrm{m} l$

\begin{tabular}{|c|c|c|c|}
\hline & $\underset{\text { acid }}{\text { glutamic }}$ & phenylalanine & glu/phen比 \\
\hline 本味淋 & 420 & 190 & 2.2 \\
\hline 同增䤇 $(1: 0.5)$ & 690 & 130 & 5.3 \\
\hline 同增醇 $(1: 1)$ & 1280 & 90 & 14.2 \\
\hline 京增醇 (1:2) & 1600 & 60 & 26.6 \\
\hline 本 味 淋 & 360 & 230 & 1.5 \\
\hline 同增醇 $(1: 0.5)$ & 540 & 100 & 5.4 \\
\hline 阔增醸 $(1: 1)$ & 1060 & 80 & 13. 2 \\
\hline 同增醇 $(1: 2)$ & 1560 & 60 & 26.0 \\
\hline
\end{tabular}

10) Glutamic acid/phenylalanine 比

現在のところ増醸みりんの調味液中にはアミノ酸とし てはグルタミン酸のみしか添加することが許されていな いので増醸みりんのアミノ酸量が堌醸しないみりんと同 じ值になるように製造すればグルタミン酸量が増大して 扣り,グルタミン酸と他のアミノ酸との量比が大きくな っているはずである。比較するアミノ酸はグルタミン酸 以外のアミノ酸であればどれでもよいはずであるがフェ ニィルアラニンを他のアミノ酸の代表として測定し，そ の比をだしてみた。その結果を第 3 表に示した。この比 と増醸割合との関係が直線に近い関係になり相関が大き いことがわかる。この Glutamic acid/phenylalanine 比 は中村 ${ }^{4)}$, 井上5) らの分析值とる割合よく一致する值と なった。したがって増醇割合を推定するには良い力法で あると思われる。ただしグルタミン酸を加えないで増䣼 した場合にはこの比には変化は生じないがアミノ酸量の 方が減少するのでそららで推定することができる。

11）乳酸・コハク酸/グライコール酸比

この比率も上記 Glutamic acid/phenylalanine 比と 同様に本みりん中の比が㟫昰一定で, 調味液中に入れら れる酸がきまっているので増醸割合推定には比較的よい 方法であると予想される。分母の酸はみりん中の酸なら ばどの酸でもよいわけであるが比較的多い酸であるグラ ィコール酸を代表に用いた。その結果を第 4 表に示す。

第 4 表 味淋中の乳酸・コハク酸/グライコール酸比

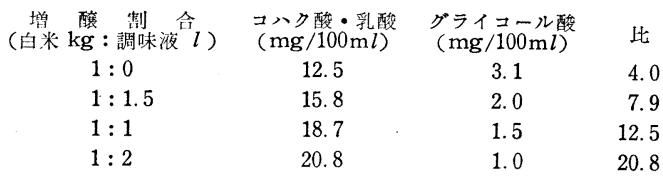


割合よい比例関係をなしていることがわかる。しかしこ

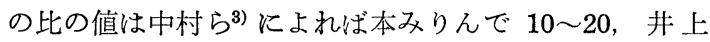
ら7)によれば 2〜8 であり，基本として考光るべき数字 のふれが大きく，みりん製造条件に何か大きな变動要因 があるのではないかと考光られ，この数字のみによって 增醸割合を推定するのは問題がありすぎると考えられ る。

\section{2. 桷歩合と各種分析数値との関係}

以上の実験によって Xanthoprotein 反応值, Buffer action 值, $\alpha-$ アミラーゼ力価, $\mathrm{pH}$, 硬度, リン, 色度, Glutamic acid/phenylalanine 比, 乳酸・コハク酸/グ ライコール酸比等が増醸との相関が比較的大きいことが わかった。しかし, これらのらち Glutamic acid/phenyalanine 比をのぞくといずれも色々の製造, 貯蔵条件 によってある程度変動することが考兄られ，かつ又実際

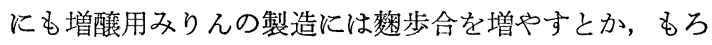
み温度をやや高くして溶解をよくし，アミノ酸・ペプタ イド等をやや増大させるような製造法がとられている例 あある。そこで比較的関係が大きいと思われる麴歩合を 取りあげこれと上記成分の一部との関係を調べてみた。 その結果を第 5 表に示す。いずれる整歩合を増大させる
第 5 表 䴴歩合と成分との関係

\begin{tabular}{|c|c|c|c|c|c|c|c|}
\hline $\begin{array}{l}\text { 猌步合 } \\
(\%)\end{array}$ & $\begin{array}{l}\text { Xantho } \\
\text { protein } \\
\text { 区㐫値 }\end{array}$ & $\begin{array}{l}\text { Buffer } \\
\text { action } \\
\text { 值 }\end{array}$ & 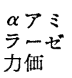 & $\mathrm{pH}$ & 全硬 & $\mathbf{P}$ & 色度 \\
\hline 10 & 0.21 & 11.0 & 31 & 5.7 & 35.6 & 56 & 0.08 \\
\hline 14 & 0.33 & 13.2 & 38 & 5.75 & 38.4 & 61 & 0.09 \\
\hline 17 & 0.47 & 14.5 & 47 & 5.8 & 43.8 & 65 & 11 \\
\hline
\end{tabular}

とある程度, 数值が大きくなって扔り相関があることが わかる。したがって製造条件のぶれも増醇推定の場合に 相当考慮に入れる必要があることがわかる。ただし倍量 又は 2 倍量の增醸のものにくらべるとやや数値変化の少 ないものが多い。

\section{3. みりんの新古之成分との関係}

みりんの成分に影響の大きいものとして麳歩合のほか に貯蔵日数が考兄られる。そこで, 新みりん（上槽後 2 ヶ月以内）と古みりん（1 年以上）を集め分析を行なっ てみた。その結果は第 6 表のと招りで，古くなると色度 がまし, 直糖\%が大きくなっている。新みりんでは增 醇の方が粘度が大となっているが，古みりんでは差がな くなっている。Xanthoprotein 反応值， $\alpha$ アミラーゼ力 価では增醕との関係がきれいにでている。したがって色 度, 直糖 \%, 粘度等はあまり信頼できる分析数值とはい

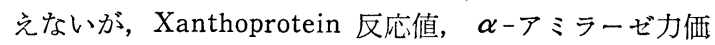

第 6 表昧淋の新古と成分との関係

\begin{tabular}{|c|c|c|c|c|c|c|c|c|c|c|c|}
\hline 味 & 林 & 增䤑率 & 総酸度 & $\begin{array}{l}\text { アミノ } \\
\text { 酸度 }\end{array}$ & 色 度 & $\begin{array}{l}\text { Xantho } \\
\text { protein } \\
\text { 反応值 }\end{array}$ & $\mathrm{pH}$ & $\begin{array}{l}\alpha ア ミ \\
\text { ラーゼ } \\
\text { 力価 }\end{array}$ & $\begin{array}{c}\text { 菑 }(\%) \\
\text { 糖 }\end{array}$ & 全 $(\%)^{\text {糖 }}$ & $\begin{array}{l}\text { 粘 度 } \\
\text { (c. p) }\end{array}$ \\
\hline & 1 & $(1: 0)$ & 0.75 & 1.53 & 0.162 & 0.83 & 5.5 & 71.6 & 42.6 & 45.2 & 9.7 \\
\hline 古 & 2 & $(1: 0)$ & 0.78 & 1.15 & 0.140 & 0.46 & 4.9 & 30.0 & 43.4 & 46.6 & 10.0 \\
\hline 淋 & 3 & $(1: 0.4)$ & 0.88 & 1.10 & 0.128 & 0.27 & 4.5 & 25.8 & 42.0 & 44.8 & 9.9 \\
\hline & 4 & $(1: 0.6)$ & 0.64 & 0.90 & 0.118 & 0.34 & 4.7 & 17.0 & 42.4 & 45.6 & 9.9 \\
\hline & 5 & $(1: 0)$ & 0.48 & 1. 22 & 0.102 & 0.54 & 6.3 & 50.0 & 39.6 & 43.4 & 8.8 \\
\hline 新 & 6 & $(1: 0)$ & 0.57 & 1.19 & 0.108 & 0.39 & 5.3 & 39.2 & 39.2 & 43.8 & 8.7 \\
\hline 森 & 7 & $(1: 0.5)$ & 0.45 & 1.05 & 0.068 & 0.25 & 5.5 & 15.8 & 40.6 & 47.4 & 10.1 \\
\hline & 8 & $(1: 1)$ & 0.52 & 0.95 & 0.085 & 0.20 & 4.9 & 15.0 & 40.4 & 47.4 & 10.1 \\
\hline
\end{tabular}

第 7 表市販味淋の分析結果

\begin{tabular}{|c|c|c|c|c|c|c|c|c|c|c|c|c|c|c|c|}
\hline 味淋 & 色度 & 濁度 & $\begin{array}{l}\text { 総酸 } \\
\text { 度 }\end{array}$ & $\begin{array}{l}\text { アミノ } \\
\text { 酸度 }\end{array}$ & $\begin{array}{l}\text { ポー } \\
x\end{array}$ & $\mathrm{pH}$ & $\begin{array}{l}\text { 全硬 } \\
\text { 度 }\end{array}$ & $\begin{array}{l}\text { yン } \\
\text { 濃度 }\end{array}$ & 直糖 & 全糖 & $\begin{array}{l}\text { Xantho } \\
\text { protein } \\
\text { 反応值 }\end{array}$ & $\begin{array}{l}\alpha ア ミ \\
\text { ラーゼ } \\
\text { 力価 }\end{array}$ & $\begin{array}{l}\text { glutamic } \\
\text { acid }\end{array}$ & $\begin{array}{l}\text { phenyl } \\
\text { alanine }\end{array}$ & $\begin{array}{c}\text { glu/phen } \\
\text { 比 }\end{array}$ \\
\hline 1 & 0.088 & 16 & 0.58 & 0.91 & 20.3 & 4.85 & 35.6 & 71 & 42.0 & 46.8 & 0.255 & 28.0 & 236 & 54 & 4. 35 \\
\hline 2 & 0.076 & 22 & 0.56 & 1. 34 & 19.8 & 5.40 & 45.0 & 86 & 42.0 & 45.4 & 0.327 & 63.0 & 202 & 78 & 2.59 \\
\hline 3 & 0.188 & 21 & 0.83 & 1. 21 & 20.5 & 4.70 & 48.0 & 80 & 43.2 & 46.2 & 0.402 & 36.7 & 250 & 90 & 2.78 \\
\hline 4 & 0.145 & 18 & 0.26 & 0.69 & 19.9 & 5.45 & 74.0 & 96 & 41.6 & 44.8 & 0.350 & 35.7 & 556 & 62 & 8.98 \\
\hline 5 & 0.058 & 22 & 0.38 & 0.76 & 19.7 & 4.95 & 33.0 & 52 & 36.6 & 39.8 & 0.139 & 21.5 & 438 & 32 & 13.7 \\
\hline 6 & 0.045 & 12 & 0.13 & 0.15 & 20.2 & 5.15 & 12.0 & 23 & 41. 6 & 44.4 & 0.118 & 2.6 & 456 & 37 & 12.3 \\
\hline 7 & 0.075 & 14 & 0.60 & 1.58 & 19.7 & 5.15 & 44.4 & 62 & 38.9 & 41.6 & 0.370 & 2.9 & 230 & 126 & 1.83 \\
\hline 8 & 0.115 & 20 & 1. 33 & 1.95 & 19.8 & 4.70 & 78.0 & 121 & 39.6 & 47.0 & 0.780 & 84.0 & 374 & 124 & 3.02 \\
\hline 9 & 0.32 & 13 & 0.58 & 0.84 & 17.5 & 4. 65 & 35.0 & 47 & 38.6 & 39.8 & 0.140 & 6.5 & 155 & 36 & 4. 31 \\
\hline 10 & 0.145 & 44 & 0.93 & 0.81 & 20.6 & 4.25 & 37.6 & 68 & 38.8 & 46.8 & 0.262 & 16.6 & 140 & 42 & 3.33 \\
\hline 11 & 0.006 & 16 & 0.38 & 1. 31 & 20.5 & 5.50 & 43.6 & 59 & 39.4 & 45.8 & 0.230 & 2.7 & 420 & 80 & 5.25 \\
\hline 12 & 0.172 & 21 & 0.75 & 1.00 & 20.4 & 4.70 & 85.0 & 49 & 41.6 & 45.6 & 0.400 & 44.4 & 438 & 136 & 3.22 \\
\hline 13 & 0.085 & 18 & 0.73 & 1.35 & 18.8 & 4.60 & 46.0 & 62 & 39.0 & 41. 6 & 0.243 & 9.0 & 687 & 52 & 13.2 \\
\hline 14 & 0.058 & 13 & 0.58 & 1.70 & 19.6 & 5.25 & 66.0 & 79 & 37.6 & 44.2 & 0.510 & 3.0 & 205 & 94 & 2.18 \\
\hline 15 & 0.090 & 17 & 0.57 & 0.70 & 20.0 & 4.75 & 32.4 & 70 & 43.4 & 44.4 & 0.230 & 37.8 & 132 & 36 & 3.67 \\
\hline 16 & 0.052 & 13 & 0.29 & 0.51 & 20.3 & 5.45 & 31.6 & 61 & 43.8 & 45.6 & 0.228 & 36.6 & 124 & 30 & 4. 13 \\
\hline 17 & 0.048 & 13 & 0.25 & 1.35 & 19.9 & 5.85 & 41.0 & 56 & 41.2 & 44.4 & 0.330 & 55.2 & 184 & 102 & 1.80 \\
\hline 18 & 0.048 & 18 & 0.20 & 0.52 & 19.8 & 5.75 & 31.0 & 43 & 41.0 & 45.0 & 0.108 & 5.8 & 88 & 38 & 2.32 \\
\hline 19 & 0.042 & 14 & 0.61 & 1.50 & 20.2 & 4.95 & 40.0 & 58 & 38.8 & 45.2 & 0.113 & 3.0 & 1175 & 64 & 18. 36 \\
\hline 20 & 0.075 & 14 & 0.41 & 0.93 & 20.1 & 5. 20 & 29.0 & 49 & 40.0 & 45.6 & 0.188 & 31.5 & 640 & 38 & 16.84 \\
\hline
\end{tabular}


第 8 表 市販みりん分析数值より増醆率の推定

\begin{tabular}{|c|c|c|c|c|c|c|c|c|}
\hline 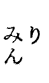 & 色度 & 全硬 & リン & $\begin{array}{l}\text { Xantho } \\
\text { protein } \\
\text { 反応値 }\end{array}$ & $\begin{array}{l}\alpha ア ミ \\
\text { ラー艺 } \\
\text { 力価 }\end{array}$ & $\begin{array}{c}\text { glu/phen } \\
\text { 比 }\end{array}$ & 平均 & $\begin{array}{l}\text { 修正 } \\
\text { 值 }\end{array}$ \\
\hline 1 & 0.75 & 1.5 & 0 & 0.6 & 0.8 & 0.3 & 0.5 & 0. \\
\hline 2 & 1.0 & 0 & 0 & 0 & 0 & 0 & 0.16 & 0 \\
\hline 3 & 0 & 0 & 0 & 0 & 0.6 & 0 & 0.1 & 0 \\
\hline 4 & 0 & 1.7 & 1.5 & 1.5 & 1.2 & 1.0 & 1.1 & \\
\hline 5 & 1.6 & 1.0 & 0.6 & 1.0 & 2.0 & 1.0 & 1.1 & \\
\hline 6 & 2.0 & 3.0 & 3.0 & 3.0 & 1.3 & 1.3 & 2.6 & \\
\hline 7 & 1.0 & 0 & 0.2 & 0.2 & 2.0 & 0 & 0.5 & \\
\hline 8 & 0.5 & 0 & 0 & 0 & 0 & 0 & 0.1 & \\
\hline 9 & 3 & 0.8 & 0.7 & 1.5 & 2.0 & 0.2 & 1.3 & \\
\hline 10 & 0 & 0.7 & 0.1 & 0.6 & 1.5 & 0.1 & 0.5 & \\
\hline 11 & 1.7 & 0.1 & 0.4 & 0.7 & 2.0 & 0.5 & 0.9 & \\
\hline 12 & 0 & 0 & 0.7 & 0 & 0 & 0.2 & 0.2 & \\
\hline 13 & 1.0 & 0 & 0.3 & 0.6 & 2.0 & 1.0 & 0.8 & \\
\hline 14 & 1.5 & 0 & 0 & 0 & 2.0 & 0 & 0.6 & \\
\hline 15 & 0.7 & 1.0 & 0 & 0.7 & 0.5 & 0.2 & 0.5 & \\
\hline 16 & 2.0 & 1.0 & 0.3 & 0.7 & 0.6 & 0.3 & 0.8 & \\
\hline 17 & 2.5 & 0.3 & 0.5 & 0.2 & 0.1 & 0 & 0.6 & \\
\hline 18 & 2.5 & 1.2 & 1.0 & 2.0 & 2.0 & 0 & 1.5 & \\
\hline 19 & 2.5 & 0.5 & 0.5 & 2.0 & 2.0 & 1.3 & 1.4 & \\
\hline 20 & 1.2 & 1.2 & 0.7 & 1.0 & 0.7 & 1.2 & 1.0 & \\
\hline
\end{tabular}

は利用可能と考えられる。

\section{4. 市販みりんの分析値および增醸比率の推定}

市肘みりんの分析値叔よびその数值による増醸割合の 推定を第 7,8 表に示す。製造条件が皆それぞれ異なっ ているので一律に増醸割合を推定するのは問題があり, 相当大きな誤差があるのを承知の上で，これら分析数值 より増䤈割合の推定を行なってみた。基準は第 1 表の数 字を用いた。壃醉割合の推定に利用した分析数値は第 8 表にあるように色度, 全硬度, リン, Xanthoprotein 反

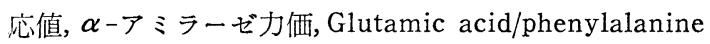
比を用いた。これらの推定值には相当のふれがあるので まずその平均值を出した。さらに同じような数字がなら

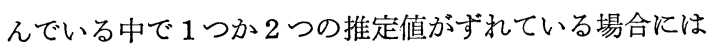
ずれた数字の比重を小さくして再計算した。又 Glutamic acid/phenylalanine 比が小さくてもアミノ酸量の 少ないものはグルタミン酸を加えずに増醉を行なったも のとして修正を行なった。これら色々の綜合的な判定に よる修正值を第 8 表の一番右に示した。この修正值が一 番正しいものに近いと仮定すると比較的この值に近い数 值を示しているのは Glutamic acid/phenylalanine 比で,

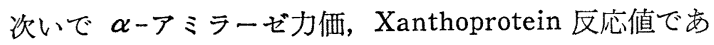
る。もっともずれの大きいのが色度である。さらにこの 修正值が割合正しいるのと仮定して全体をみると増醸を していないと思われるもの 3 点, $1: 1.5$ 以上の増醇を 行なっているものが 3 点ある。大部分は $0.2 \sim 1.2$ の範 囲に入ってくる。これは製造に特いて増醸が広く行なわ れていることをらかがわせる数字である。これらの推定 はふれが相当大きく拴拈よその推定しかできないことも たしかである。しかしみりん品質というものを考える上 に特いてはひとつの指標となりらるものであるよらな感 じがする。

\section{1) 国税庁所定分析法}

2) 実験化学講座, 25 巻, p. 265 , 丸善戴店

3) 中村精一, 竹内五男, 岛田 洯, 本誌 60, 533 (1965)

4) " " " " 60, 447 (1965)

5) 井上浩, 銵鳥飼勝, 内田正裕, 森田日出男, 清藤幸一本誌, 57, 332 (1962)

6) 井上 浩, 内田正裕, 醊工, 42, 503 (1964)

7) 井上 浩, 内田正裕, 宮部敏則, 醴工, 44, 71 (1966)

8) 佐藤 倍, 本誌, 50, 356 (1955)

9) 佐藤 信, 原田哲夫, 本誌, 50, 113 (1955)

10）徳村治彦, 山下 勝, 梅村泰一, 河村稳, 愛食試年報, 3, 15 (1962)

11）徳村治彦, 山下 勝, 要食試年報, 4, 1 (1963) 
J. Soc. Brew. Japan, 1973, Vol. 68, No. 4, p. $291 \sim$ p. 296

\title{
Discrimination method between pure mirin and the partly enlarged ones.
}

\author{
Masaru Yamashita, Mikio Yamada \\ (The food Research Institute Aichi Prefecture)
}

\begin{abstract}
Sometime, mirin is enlarged its volume by the addition of alcohol, glutamic acid, and sugars. Estimation of the enlargement ratio in mirin by the analysis of chemical composition was examined. Very close correlations were found between the enlargement ratio and the glutamic acid/phenylalanine ratio, lactic acid \& succinic acid/glycollic acid ratio, xanthoprotein reactivation value, buffer action, $\alpha$-amylase activity, hardness, and mineral contents in mirin. Especially, the glutamic acid/phenylalanine ratio was a very useful discriminating index. Chemical composition of the marketing mirin was analyzed and the estimation of the enlargement ratio was done based upon the above-mentioned indexes.
\end{abstract}

As the results, almost all mirin marketed at present were found to had somewhat been enlarged the volume with the additives; the ratios were 0.2 to 1.2 to the weight of the raw polished rice. Such analytical values, also, clearly revealed that the enlargement process was widely applied in the mirin breweries. 